\begin{abstract}
Iranica
Abstracta Iranica Revue bibliographique pour le domaine irano-aryen

Volume 42-43 | 2021

Comptes rendus des publications de 2019-2020
\end{abstract}

\title{
Matthias Binder (éd. et trad.). Johannes von Dalyatha. Geistliche Reden
}

Florence Jullien

\section{(2) OpenEdition \\ Journals}

Édition électronique

URL : https://journals.openedition.org/abstractairanica/51996

DOI : 10.4000/abstractairanica.51996

ISSN : 1961-960X

Éditeur :

CNRS (UMR 7528 Mondes iraniens et indiens), Éditions de l'IFRI

Référence électronique

Florence Jullien, « Matthias Binder (éd. et trad.). Johannes von Dalyatha. Geistliche Reden », Abstracta Iranica [En ligne], Volume 42-43 | 2021, document 11, mis en ligne le 30 décembre 2020, consulté le 14 décembre 2022. URL : http://journals.openedition.org/abstractairanica/51996 ; DOI : https://doi.org/ $10.4000 /$ abstractairanica. 51996

Ce document a été généré automatiquement le 14 décembre 2022.

Tous droits réservés 


\title{
Matthias Binder (éd. et trad.). Johannes von Dalyatha. Geistliche Reden
}

\author{
Florence Jullien
}

\section{RÉFÉRENCE}

Matthias Binder (éd. et trad.). Johannes von Dalyatha. Geistliche Reden. (Paradies der Väter Schriften syrischer Mystiker), sous la dir. de Gabriel Bunge, Grigory Kessel et Gerd Vatter. Beuron : Beuroner Kunstverlag, 2019, 176 p. ISBN 978-3870713690

1 Dans la suite des travaux du Père Robert Beulay et de Nadira Khayyat qui firent connaître l'œuvre de cet auteur mystique syro-oriental du VIII ${ }^{e}$ siècle, Matthias Binder (Université Philipps de Marburg) entreprend ici à nouveaux frais une nouvelle traduction commentée, proposée en allemand, des deux œuvres majeures de Jean de Dalyatha: ses Lettres et ses Homélies ou enseignement spirituel. Les écrits de ce maître de spiritualité monastique syriaque orientale furent rapidement intégrés par l'Église syro-orthodoxe (et plus tard par la tradition arabe chrétienne puis copte et éthiopienne) comme auteur de référence. On a pu noter l'influence marquée de Grégoire de Nysse, de Jean d'Apamée, et particulièrement des grands moines écrivains ascétiques de l'Égypte, Évagre le Pontique et le Ps.-Macaire notamment. Dans la suite des travaux de ses prédécesseurs, l'A. montre comment le moine syro-oriental effectue dans son enseignement une description très précise des processus spirituels et psychologiques, et parfois même physiques, de l'expérience mystique.

2 [Ce compte rendu concerne également le $\left.\mathrm{n}^{\circ} 10\right]$ 


\section{AUTEURS}

FLORENCE JULLIEN

CNRS, CERMI, Paris 